\title{
Effect of Lactofen, Azoxystrobin, and Genotypes on Charcoal Rot, Phomopsis Seed Decay, and Pod and Stem Blight in Soybean
}

Cory Cross, Allen Wrather, Kent Fothergill, and Grover Shannon, University of Missouri, Portageville 63873; Shuxian Li, United States Department of Agriculture-Agricultural Research Service, Stoneville, MS 38776; Calvin Shumway, Arkansas State University, Jonesboro 72467; and John Rupe, University of Arkansas, Fayetteville 72701

\begin{abstract}
Cross, C., Wrather, A., Fothergill, K., Shannon, G., Li, S., Shumway, C., and Rupe, J. 2012. Effect of lactofen, azoxystrobin, and genotypes on charcoal rot, Phomopsis seed decay, and pod and stem blight in soybean. Plant Dis. 96:1154-1158.

Yield-limiting diseases such as charcoal rot and Phomopsis seed decay have a significant impact on the economic potential for soybean because there are few methods for management of these diseases. The objectives of this study were to determine the development of charcoal rot, infection of seed by Phomopsis spp., and severity of pod and stem blight on Asgrow 4403, Delta Pine 5806, United States Department of Agriculture-introduced DT 97-4290 and plant introduction (PI) number PI 567562A, and Asgrow 4403 treated and not treated with lactofen or azoxystrobin. This is the first report of high levels of resistance in PI

567562A to charcoal rot, and resistance in this PI was greater than for DT 97-4290. Application of lactofen at growth stage R1 and azoxystrobin at either planting, R3, or R6 had no significant impact on severity of charcoal rot, percentage of harvested seed infected by Phomopsis spp., or severity of pod and stem blight on genotype Asgrow 4403. Of four genotypes evaluated, none were resistant to infection by Phomopsis spp. The genotypes Asgrow 4403, DP 5806, and DT 974290 were susceptible to pod and stem blight and PI 567562A was resistant.
\end{abstract}

Charcoal rot, caused by Macrophomina phaseolina (Tassi) Goid., is widespread in many parts of the world and affects several important crops. Charcoal rot ranked second to sixth among diseases that suppressed soybean yield in the United States from 1996 to 2007 (21). Charcoal rot suppressed soybean yields most often in Arkansas, Illinois, Indiana, Kansas, Kentucky, Missouri, Mississippi, and Tennessee (21). The total for soybean yield suppression due to charcoal rot was variable among years due to the impact of heat stress and drought on severity of this disease.

Aboveground symptoms of charcoal rot in soybean generally appear after flowering, particularly at R5 (5), R6, and R7 growth stages. Diseased plants may wilt and prematurely die, with senesced leaves remaining attached to petioles (13). When damage to soybean is severe, a light gray or silvery discoloration of the epidermal and subepidermal tissues develops in the taproot and lower part of the stem (22).

Severity of charcoal rot on soybean is greater when soils are warmer than $28^{\circ} \mathrm{C}$ and as soil moisture becomes limiting (13). A strong correlation is reported between drought and severity of damage to soybean $(13,22)$. Infections due to $M$. phaseolina remain latent until environmental stresses coincide with growth stages R1 to R7. During these stress periods, the colony forming units (CFU) in root and lower stem tissues increase as the soybean plant matures, and premature plant death may occur (13).

Management strategies for charcoal rot of soybean are very limited, and these strategies do not completely protect soybean against M. phaseolina. Resistant cultivars are not yet available to growers. There is variation among soybean genotypes in rate of root tissue colonization by $M$. phaseolina. For example, Paris et al. released a genotype (DT 97-4290) rated as moderately resistant to charcoal rot (17) but this resistance has not yet been incorporated into highyielding cultivars. Currently available management strategies are cultural methods to minimize drought stress such as reduced plant

Corresponding author: C. Cross, E-mail: crosscb@ missouri.edu

Accepted for publication 28 February 2012.

http://dx.doi.org/10.1094/PDIS-09-11-0810-RE

(C) 2012 The American Phytopathological Society populations, management of planting dates, irrigation, and selection of cultivars with tolerance to mid-season drought stress (23). Because there are no commercial soybean cultivars available with resistance to charcoal rot, additional sources of host resistance and other methods are needed.

Phomopsis seed decay (PSD) is primarily caused by Phomopsis longicolla Hobbs, as well as other Phomopsis spp. and Diaporthe spp., and is an endemic seed pathogen in soybean production areas worldwide $(9,14)$. Soybean yield suppression due to PSD in the top 10 producing countries was estimated to be approximately 0.19 million metric tons in 1994 (20). Estimated yield suppression due to PSD in the United States was 0.38 to 0.43 million metric tons from 1996 to 2007 (21).

PSD occurs in most soybean production areas of the United States but particularly in Arkansas, Illinois, Indians, Kansas, Kentucky, Missouri, Mississippi, and Tennessee (21). It is more frequently a problem in the mid- to southern United States because of the adoption of the early soybean production system, which results in disease-favorable environmental conditions during seed maturation $(9,11)$. Incidence and severity of this disease depend primarily on the environmental conditions (24). PSD is most prevalent when seed production occurs during hot, humid weather and when soybean harvest is delayed due to rain. PSD symptoms on soybean seed can range from seed with no external symptoms to shriveled and elongated seed, or cracked seed coats that are chalky white in appearance. Seed with PSD often will not germinate or are slow to germinate (20). Soybean pods can be infected at any point after they form on the plant. Phomopsis and Diaporthe spp. colonize seed coats, then the cotyledons and plumules (20). Mycelia invade ovules and developing seed through the funiculus and hilum. PSD lowers the quality and quantity of seed oil and can increase incidence of moldy and split seed (9).

Several methods have been used to reduce incidence of PSD, such as rotating soybean with non-legume crops that are not hosts to PSD and traditional tillage practices to disrupt spore dissemination (9). Unfortunately, these methods are not reliable. Foliar-applied fungicides have reduced the percentage of seed infected by Phomopsis spp. (16) in some but not all studies (24). Harvesting seed when first mature will minimize PSD (14) but weather may delay harvest. Delayed planting or planting late-maturing cultivars so that seed mature during cooler weather of early fall rather than hot, dry 
weather of mid- to late summer would be a reliable control method for management of this disease; however, yields are generally lower for late than traditional planting dates (25). Planting resistant cultivars is best for PSD management but few are available (25).

Pod and stem blight is caused by a complex of fungi that include Diaporthe phaseolorum var. sojae (Lehman) Wehm., P. sojae Lehman, and P. longicolla Hobbs (8). Pod and stem blight is recognized by the linear rows of dark pycnidia on dead or senescing stems, petioles, and pods. These pathogens overwinter in soybean plant debris and infected seed. Optimum conditions for disease development are high rainfall, high temperatures, and high humidity (2).

A novel method for management of Sclerotinia stem rot, caused by Sclerotinia sclerotiorum (Lib.) de Bary, was reported by Dann et. al. (4). They reported that application of lactofen herbicide at $\mathrm{R} 1$ growth stage of soybean reduced the incidence of this disease. Nelson et. al. (15) reported that lactofen could cause a phytoalexin production response in soybean to reduce incidence of Sclerotinia spp. infection (15). The patent application for diphenyl ether (e.g., lactofen) induction of systemic resistance in plants, submitted by Valent U.S.A. Corporation and the Ohio State University Research Foundation, indicated that lactofen could induce a systemic resistance response in plants, thereby protecting plants against a broad range of plant pathogens and diseases, including charcoal rot (7). The affect of lactofen on charcoal rot, percentage of seed infected by Phomopsis spp., and pod and stem blight on field-grown soybean is not known.

The objectives of this study were to determine the development of charcoal rot, infection of seed by Phomopsis spp., and severity of pod and stem blight on Asgrow 4403, Delta Pine (DP) 5806, United States Department of Agriculture-introduced DT 97-4290 and plant introduction (PI) number PI 567562A, and Asgrow 4403 treated and not treated with lactofen or azoxystrobin. These genotypes were selected because results from previous field trials not yet published showed that Asgrow 4403 was susceptible and the other genotypes were moderately resistant to M. phaseolina.

\section{Materials and Methods}

Plots were established at the University of Missouri near Portageville, MO in the same location during 2009 and 2010 on a Tiptonville silt loam (fine-silty, mixed, superactive, thermic, oxyaquic Argiudoll). Prior to planting each year, the field was disked twice, and row beds (75- $\mathrm{cm}$ spacing) were formed. Plots were $4.6 \mathrm{~m}$ long and four rows wide. The top $10 \mathrm{~cm}$ of each bed was pushed off just prior to planting to form a flat-top ridge. Seed was planted at a rate of 26 seeds per row meter. Recommended agronomic practices from the University of Missouri Extension were used for pest control, fertilization, and irrigation (3).

Azoxystrobin (Syngenta Crop Protection, Greensboro, NC) was applied in furrow at planting $\left(151 \mathrm{~g}\right.$ a.i./ $\left./ \mathrm{ha}^{-1}\right)$ or applied to foliage of Asgrow 4403 at R3 and R6 growth stages at three rates: 109, 164, and $219 \mathrm{~g}$ a.i./.ha ${ }^{-1}$. Lactofen (Valent USA Corporation, Walnut Creek, CA) was applied to foliage of AG 4403 at R1 growth stage at three rates: 70,140 , and $210 \mathrm{~g}$ a.i./. $\mathrm{ha}^{-1}$. Soybean DP 5806 and genotypes DT 97-4290 and PI 567562A were not treated with either the fungicide or herbicide. Rates of lactofen and azoxystrobin included in this study were within label recommendations. These treatments were applied in water with a tractor-mounted $\mathrm{CO}_{2}$-powered boom sprayer calibrated to deliver 187 liters $\mathrm{ha}^{-1}$ at $207 \mathrm{kPa}$.

Plants were evaluated for phytotoxicity due to lactofen 7 days after treatment. A 1-to-10 scale was used, where $1=$ no symptoms and $10=$ severe symptoms. Plots were evaluated for foliar disease severity at R5 and 14 days after each application of foliar fungicides and for severity of pod and stem diseases at R8. Disease severity was evaluated using a 0-to-9 scale developed by the Southern Soybean Disease Workers, where $0=$ no disease and $9=90 \%$ of leaf or stem tissue diseased (19). Treatments were arranged in a randomized complete block with four replications (10).

Ten plants at R7.5 growth stage were arbitrarily selected and dug from the two outside rows of each plot. The lower stem and root of each plant was separated from the upper stem at the cotyledonary node, and both were allowed to air dry. Each was split to determine internal tissue discoloration due to charcoal rot using a 1-to-5 scale, where $1=$ no $M$. phaseolina microsclerotia visible in tissue and $5=$ vascular tissue darkened due to high numbers of microsclerotia in tissue (12). The lower stem and roots of each plant were washed and then ground in a Wiley Mill, model ED-5 (Swedesboro, NJ), using a 1-mm sieve. The mill was thoroughly cleaned between each sample.

A $0.5-\mathrm{g}$ portion of the root tissue was transferred to a $250-\mathrm{ml}$ flask, $100 \mathrm{ml}$ of Cholorneb-Mercury-Rose Bengal agar was added, and it was incubated in $45^{\circ} \mathrm{C}$ water bath for $20 \mathrm{~min}$. The contents were poured into 10 petri plates, and incubated in the dark at $33^{\circ} \mathrm{C}$ for 7 days, and then the colonies of $M$. phaseolina were counted (22).

The center two rows of each plot were harvested by combine. The seed were weighed and tested for moisture to determine yield at $13 \%$ moisture. A 500-g sample of harvested seed from each plot was stored in a paper bag at $25^{\circ} \mathrm{C}$ and analyzed within 30 days for percentage of seed infected with Phomopsis spp. In all, 100 arbitrarily chosen seeds from each plot were disinfected in a $0.5 \%$ sodium hypochlorite for $5 \mathrm{~min}$, rinsed in sterile distilled water, and placed on acidified ( $\mathrm{pH} 4.5$ ) Difco (Becton, Dickinson \& Company, Sparks, MD) potato dextrose agar in petri dishes (24). Five seeds were placed on each culture dish and incubated under fluorescent lights at $25^{\circ} \mathrm{C}$. Phomopsis spp. were identified based on morphological characteristics 7 days later $(1,20)$.

Statistical analysis of data was performed using the SAS mixedmodel procedure (SAS Institute Inc., Cary, NC). Mean separation was evaluated through a series of protected pairwise contrasts among all treatments (18).

\section{Results}

Analysis of variance for discoloration of internal lower-stem tissue due to M. phaseolina, CFU of M. phaseolina per $0.5 \mathrm{~g}$ of dry root, percentage of harvested seed infected by Phomopsis spp., severity of pod and stem blight, and yield indicated that there were year-treatment interactions (Table 1).

Analysis of variance for phytotoxicity due to application of lactofen indicated that there was a significant year-treatment interaction (Table 1). Lactofen damage to soybean leaves was observed 7 days after application. Treatment with lactofen caused some leaf burn on soybean in 2009 and 2010, and the severity of injury to soybean increased as rates of herbicide applied increased (Table 2).

Internal stem discoloration was significantly lower for DP 5806, DT 97-4290, and PI 567562A than AG 4403 in both years. Internal stem discoloration was lower for PI 567562A than for DP 5806 in both years (Table 3). CFU were significantly lower for DP 5806

Table 1. Analysis of variance for phytotoxicity due to lactofen application, discoloration of internal soybean stem tissue by Macrophomina phaseolina at R7.5, CFU of $M$. phaseolina per $0.5 \mathrm{~g}$ of dry root at R7.5, percentage of harvested seed infected by Phomopsis spp. (PSD), severity of pod and stem blight symptoms at R8, and yield for years and treatments ${ }^{\mathrm{z}}$

\begin{tabular}{lccr}
\hline & \multicolumn{3}{c}{ Source of variation $(\boldsymbol{P}>\boldsymbol{F})$} \\
\cline { 2 - 4 } Variables & Year $(\mathbf{Y})$ & Treatments $(\mathbf{T})$ & $\mathbf{Y} \times \mathbf{T}$ \\
\hline Phytotoxicity & 0.3189 & $<0.0001$ & $<0.0001$ \\
Discoloration & 0.0129 & $<0.0001$ & $<0.0001$ \\
CFU & 0.0059 & $<0.0001$ & 0.0288 \\
PSD & $<0.0001$ & 0.0356 & 0.0435 \\
Pod and stem blight & $<0.0001$ & $<0.0001$ & $<0.0001$ \\
Yield & $<0.0001$ & $<0.0001$ & $<0.0001$ \\
\hline
\end{tabular}

z Years were 2009 and 2010. Treatments were foliar application of lactofen herbicide at R1 growth stage; in-furrow and foliar application of azoxystrobin to Asgrow 4403 at planting, R3, and R6 growth stages; and genotypes Delta Pine 5806, United States Department of Agriculturedeveloped line DT 97-4290, and plant introduction (PI) 567562A not treated with fungicide or herbicide. 
and PI 567562A than for AG 4403 and significantly lower for PI 567562 A than DT $97-4290$ in both years.

Stem discoloration due to $M$. phaseolina was similar between AG 4403 treated with azoxystrobin and not treated in both years. There were some significant differences in stem discoloration among the azoxystrobin treatments in 2009 and 2010 but these differences were not consistent between years. The reasons for these differences are not known. There were no significant differ-

Table 2. Phytotoxicity of lactofen herbicide applied at three rates on Asgrow 4403 in 2009 and $2010^{2}$

\begin{tabular}{lll}
\hline & \multicolumn{2}{c}{ Phytotoxicity } \\
\cline { 2 - 3 } Lactofen $\left(\mathbf{g ~ a . i . ~ h a ~}^{\mathbf{1}}\right)$ & $\mathbf{2 0 0 9}$ & $\mathbf{2 0 1 0}$ \\
\hline None & $1.0 \mathrm{~d}$ & $1.0 \mathrm{c}$ \\
70 & $2.0 \mathrm{c}$ & $2.5 \mathrm{~b}$ \\
140 & $3.0 \mathrm{~b}$ & $3.3 \mathrm{a}$ \\
210 & $5.0 \mathrm{a}$ & $3.5 \mathrm{a}$ \\
\hline
\end{tabular}

${ }^{\mathrm{z}}$ Lactofen was applied at R1 growth stage and phytotoxicity was evaluated 7 days later based on a 1-to- 10 scale, where $1=$ no damage and $10=$ severe damage. Values followed by the same letter are not significantly different $(P<0.05)$. ences in CFU of $M$. phaseolina per $0.5 \mathrm{~g}$ of dry root tissue between AG 4403 treated with azoxystrobin and not treated in both years and among azoxystrobin treatments (Table 3).

There were no differences in stem discoloration due to $M$. phaseolina or CFU between AG 4403 treated with lactofen and not treated in 2009 and 2010 (Table 3). Stem discoloration was significantly greater in 2010 for the 210 g. a.i. ha $^{-1}$ than for the 140 g. a.i. $\mathrm{ha}^{-1}$ lactofen treatment. CFU in 2009 was significantly greater for the $140 \mathrm{~g}$. a.i. ha ${ }^{-1}$ than for the $70 \mathrm{~g}$. a.i. ha ${ }^{-1}$ lactofen treatment. The reasons for these differences are not known.

Seed harvested from all plots were infected with Phomopsis spp. in 2009 but seed infection was very low in 2010, with a maximum of $1 \%$ infection (data not shown). There were no significant differences in percent harvested seed infected with Phomopsis spp. between AG 4403 treated with azoxystrobin and not treated in 2009 (Table 4).

There were no differences in percentage of seed infected with Phomopsis spp. or pod and stem blight severity between A4403 treated with lactofen and not treated and among lactofen treatments (Table 4).

Pod and stem blight symptoms were moderate on AG 4403 not treated with fungicide in 2009 and very mild in 2010 (Table 4). Symptoms of this disease were not observed on PI 567562A in

Table 3. Lactofen, azoxystrobin, and soybean genotype effects on discoloration of internal stem tissue by Macrophomina phaseolina and M. phaseolina colony forming units (CFU) in thousands in 2009 and $2010^{z}$

\begin{tabular}{|c|c|c|c|c|c|}
\hline \multicolumn{2}{|l|}{ Treatments } & \multicolumn{2}{|c|}{ Stem discoloration severity } & \multicolumn{2}{|c|}{ CFU } \\
\hline Genotype & Chemical (g a.i. ha' ${ }^{-1}$ ) & 2009 & 2010 & 2009 & 2010 \\
\hline AG 4403 & None & $4.6 \mathrm{ab}$ & $3.8 \mathrm{a}-\mathrm{d}$ & $5.7 \mathrm{ab}$ & $4.2 \mathrm{a}$ \\
\hline AG 4403 & Lactofen (70) at R1 & $4.4 \mathrm{ab}$ & $3.9 \mathrm{a}-\mathrm{d}$ & $5.2 \mathrm{~b}$ & $2.8 \mathrm{a}-\mathrm{c}$ \\
\hline AG 4403 & Lactofen (140) at R1 & $4.3 \mathrm{ab}$ & $3.6 \mathrm{~cd}$ & $8.1 \mathrm{a}$ & $2.2 \mathrm{a}-\mathrm{d}$ \\
\hline AG 4403 & Lactofen (210) at R1 & $4.2 \mathrm{ab}$ & $4.1 \mathrm{ab}$ & $7.2 \mathrm{ab}$ & $1.9 \mathrm{a}-\mathrm{d}$ \\
\hline AG 4403 & Azoxystrobin (151) in furrow & $4.5 \mathrm{ab}$ & $4.0 \mathrm{a}-\mathrm{c}$ & $6.8 \mathrm{ab}$ & $1.9 \mathrm{a}-\mathrm{d}$ \\
\hline AG 4403 & Azoxystrobin (109) at R3 & $4.5 \mathrm{ab}$ & $3.8 \mathrm{~b}-\mathrm{d}$ & $7.1 \mathrm{ab}$ & $2.8 \mathrm{a}-\mathrm{c}$ \\
\hline AG 4403 & Azoxystrobin (164) at R3 & $4.1 \mathrm{~b}$ & $3.6 \mathrm{~cd}$ & $6.4 \mathrm{ab}$ & $2.0 \mathrm{a}-\mathrm{d}$ \\
\hline AG 4403 & Azoxystrobin (219) at R3 & $4.7 \mathrm{a}$ & $3.6 \mathrm{~cd}$ & $6.8 \mathrm{ab}$ & $3.7 \mathrm{ab}$ \\
\hline AG 4403 & Azoxystrobin (109) at R6 & $4.3 \mathrm{ab}$ & $4.2 \mathrm{a}$ & $5.7 \mathrm{ab}$ & $3.1 \mathrm{a}-\mathrm{c}$ \\
\hline AG 4403 & Azoxystrobin (164) at R6 & $4.2 \mathrm{ab}$ & $3.8 \mathrm{~b}-\mathrm{d}$ & $6.2 \mathrm{ab}$ & $2.2 \mathrm{a}-\mathrm{d}$ \\
\hline AG 4403 & Azoxystrobin (219) at R6 & $4.6 \mathrm{ab}$ & $3.7 \mathrm{~cd}$ & $6.5 \mathrm{ab}$ & $3.5 \mathrm{ab}$ \\
\hline DP 5806 & None & $1.1 \mathrm{~d}$ & $2.6 \mathrm{e}$ & $1.7 \mathrm{c}$ & $0.9 \mathrm{~cd}$ \\
\hline DT $97-4290$ & None & $3.2 \mathrm{c}$ & $1.6 \mathrm{f}$ & $6.3 \mathrm{ab}$ & $3.7 \mathrm{ab}$ \\
\hline PI 567562A & None & $1.0 \mathrm{~d}$ & $1.2 \mathrm{f}$ & $0.5 \mathrm{c}$ & $0.6 \mathrm{~d}$ \\
\hline
\end{tabular}

${ }^{\mathrm{z}}$ Genotypes were Asgrow (AG) 4403, Delta Pine (DP) 5806, United States Department of Agriculture-developed line DT 97-4290, and plant introduction (PI) 567562A. Lactofen was applied at R1 growth stage. Azoxystrobin was applied in furrow at planting and foliar at R3 and R6 growth stages. Stem discoloration was evaluated at R7.5 based on a 1-to 5-scale, where $1=$ no discoloration $5=$ severe discoloration. CFU of Macrophomina phaseolina per 0.5 gram of root. Values followed by the same letter are not significantly different $(P<0.05)$

Table 4. Lactofen, azoxystrobin, and soybean genotype effects on percentage of harvested seed infected with Phomopsis spp. in 2009, and pod and stem blight severity and yield in 2009 and $2010^{\mathrm{z}}$

\begin{tabular}{|c|c|c|c|c|c|c|}
\hline \multicolumn{2}{|l|}{ Treatments } & \multirow{2}{*}{$\begin{array}{c}\text { Seed infected }(\%) \\
2009\end{array}$} & \multicolumn{2}{|c|}{ Pod and stem blight severity } & \multicolumn{2}{|c|}{ Yield $\left(\mathrm{kg} \mathrm{ha}^{-1}\right)$} \\
\hline Genotype & Chemical (g a.i. ha-1) & & 2009 & 2010 & 2009 & 2010 \\
\hline AG 4403 & None & $54.0 \mathrm{bc}$ & $6.0 \mathrm{a}$ & $2.5 \mathrm{a}$ & $3,739 \mathrm{c}-\mathrm{e}$ & $2,530 \mathrm{~b}-\mathrm{e}$ \\
\hline AG 4403 & Lactofen (70) at R1 & $61.5 \mathrm{a}-\mathrm{c}$ & $6.0 \mathrm{a}$ & $2.4 \mathrm{ab}$ & $3,781 \mathrm{~b}-\mathrm{e}$ & $2,725 \mathrm{a}-\mathrm{c}$ \\
\hline AG 4403 & Lactofen (140) at R1 & $55.5 \mathrm{bc}$ & $6.0 \mathrm{a}$ & $2.4 \mathrm{ab}$ & $4,015 \mathrm{a}-\mathrm{c}$ & $2,496 \mathrm{~b}-\mathrm{e}$ \\
\hline AG 4403 & Lactofen (210) at R1 & $52.5 \mathrm{bc}$ & $5.8 \mathrm{a}$ & $2.3 \mathrm{a}-\mathrm{c}$ & $3,730 \mathrm{c}-\mathrm{e}$ & $2,331 \mathrm{de}$ \\
\hline AG 4403 & Azoxystrobin (151) in furrow & $52.5 \mathrm{bc}$ & $6.0 \mathrm{a}$ & $2.1 \mathrm{a}-\mathrm{c}$ & $3,921 \mathrm{~b}-\mathrm{e}$ & $2,713 a-c$ \\
\hline AG 4403 & Azoxystrobin (109) at R3 & $53.5 \mathrm{bc}$ & $6.0 \mathrm{a}$ & $2.3 \mathrm{a}-\mathrm{c}$ & $3,974 \mathrm{a}-\mathrm{e}$ & $2,785 \mathrm{ab}$ \\
\hline AG 4403 & Azoxystrobin (164) at R3 & $51.5 \mathrm{c}$ & $6.0 \mathrm{a}$ & $2.3 \mathrm{a}-\mathrm{c}$ & $3,723 \mathrm{de}$ & $2,275 \mathrm{e}$ \\
\hline AG 4403 & Azoxystrobin (219) at R3 & $59.5 \mathrm{a}-\mathrm{c}$ & $6.0 \mathrm{a}$ & $2.1 \mathrm{a}-\mathrm{c}$ & $3,933 \mathrm{~b}-\mathrm{e}$ & $2,573 \mathrm{~b}-\mathrm{d}$ \\
\hline AG 4403 & Azoxystrobin (109) at R6 & $61.0 \mathrm{a}-\mathrm{c}$ & $6.0 \mathrm{a}$ & $2.3 \mathrm{a}-\mathrm{c}$ & $4,052 \mathrm{ab}$ & $2,452 \mathrm{c}-\mathrm{e}$ \\
\hline AG 4403 & Azoxystrobin (164) at R6 & $61.0 \mathrm{a}-\mathrm{c}$ & $6.0 \mathrm{a}$ & $2.1 \mathrm{a}-\mathrm{c}$ & $3,653 \mathrm{e}$ & $2,742 \mathrm{ab}$ \\
\hline AG 4403 & Azoxystrobin (219) at R6 & $61.5 \mathrm{a}-\mathrm{c}$ & $6.0 \mathrm{a}$ & $2.3 \mathrm{a}-\mathrm{c}$ & $4,039 \mathrm{a}-\mathrm{d}$ & $2,459 \mathrm{c}-\mathrm{e}$ \\
\hline DP 5806 & None & $68.0 \mathrm{a}$ & $2.3 \mathrm{~b}$ & $2.3 \mathrm{a}-\mathrm{c}$ & $4,243 \mathrm{a}$ & $2,941 \mathrm{a}$ \\
\hline DT $97-4290$ & None & $62.0 \mathrm{ab}$ & $6.0 \mathrm{a}$ & $2.4 \mathrm{ab}$ & $3,075 \mathrm{f}$ & $2,725 \mathrm{ab}$ \\
\hline PI $567562 \mathrm{~A}$ & None & $59.3 \mathrm{a}-\mathrm{c}$ & $1.0 \mathrm{c}$ & $1.0 \mathrm{~d}$ & $2,047 \mathrm{~g}$ & $1,487 \mathrm{f}$ \\
\hline
\end{tabular}

${ }^{\mathrm{z}}$ Genotypes were Asgrow (AG) 4403, Delta Pine (DP) 5806, United States Department of Agriculture developed line DT 97-4290, and plant introduction (PI) 567562A. Lactofen was applied at R1 growth stage. Azoxystrobin was applied in furrow at planting, and foliar at R3 and R6 growth stage. Phomopsis spp. was evaluated after harvest based upon percentage of seed infected from each plot. Seed infected by Phomopsis spp. was less than $1 \%$ in 2010 (data not shown). Pod and stem blight was evaluated at R8 based on a 1 to 10 scale, where $1=$ no symptoms $10=$ severe symptoms. Values followed by the same letter are not significantly different $(P<0.05)$. 
either year (Table 4). There were no significant differences in severity of this disease between AG 4403 treated with azoxystrobin and not treated or between AG 4403 treated with lactofen and not treated in 2009 and 2010

Foliar symptoms of frogeye leaf spot and other foliage diseases were not observed in either year. However, symptoms of bacterial blight were observed on PI 567562A in 2009 and 2010 (data not shown).

Yields on average were greater in 2009 than in 2010 (Table 4). Yield for DP 5806 was significantly greater than most other genotypes in both years and significantly lower for PI 567562A than all other genotypes in both years. Yields were generally similar for AG 4403 treated with azoxystrobin and not treated in 2009 and 2010. Yield was significantly different among some azoxystrobin treatments in 2009 and 2010 but these differences were not observed each year. For example, yield was significantly greater in 2009 for the 109 g. a.i. ha ${ }^{-1}$ azoxystrobin treatment at R6 than for the $164 \mathrm{~g}$. a.i. $\mathrm{ha}^{-1}$ treatment applied at R6, but the yield for the 164 g. a.i. ha ${ }^{-1}$ treatment was significantly greater than for the 109 g. a.i. ha ${ }^{-1}$ treatment in 2010. The reasons for these differences are not known. Yield was similar for A4403 treated with lactofen and not treated in both years. Yield in 2010 was significantly lower for A4403 treated with lactofen at $210 \mathrm{~g}$. a.i. ha ${ }^{-1}$ than at 70 g. a.i. ha ${ }^{-1}$ (Table 4) but this was not observed in 2009. The reason for this is not known.

\section{Discussion}

The injury to soybean due to treatments with lactofen was expected because of the warnings on the herbicide label and the injury reported previously (4). A previous study showed that treatment of soybean with lactofen at the R1 growth stage reduced the severity of Sclerotinia stem rot (4). The mechanism for this reduction in disease severity may be due to phytoalexin and isoflavone production in the plant due to lactofen application $(6,15)$. The patent for diphenyl ether (e.g., lactofen) induction of systemic resistance in plants indicated that application of lactofen to soybean may affect charcoal rot, Phomopsis seed decay, and pod and stem blight (7). In this study, lactofen treatments did not affect discoloration of internal lower stem tissue due to M. phaseolina, CFU of $M$. phaseolina per $0.5 \mathrm{~g}$ of dry root, the percentage of seed infected by Phomopsis spp., and the symptom severity of pod and stem blight. Lactofen treatment may affect severity of these diseases on other soybean genotypes or the severity of other diseases on AG 4403.

This is the first report of resistance to M. phaseolina in PI 567562A. Resistance to M. phaseolina in PI 567562A is not complete because this pathogen did colonize roots but colonization was lower than for other genotypes in this study. Unfortunately, the low yield potential of this PI may limit its usefulness in soybean breeding programs directly. In addition, symptoms of bacterial blight, caused by Pseudomonas savastanoi pv. glycinea (Coerper) Gardan et. al., were severe on this PI in this study, and this susceptibility may also limit the usefulness in soybean breeding programs. Resistance to M. phaseolina in DT 97-4290 has been previously reported (17). The resistance to charcoal rot in DP 5806, as shown by low levels of discoloration of internal stem tissue and low CFU, was similar to PI 567562A. However, DP 5806 matures later (MG 5.8) than PI 567562A (MG 4) and DT 97-4290 (MG 4.7), and differences in air and soil temperatures during the R5 to R8 growth stages of these genotypes may influence development of $M$. phaseolina in stem tissue.

During the 2009 growing season, harvest was delayed due to heavy rainfall, and this may have resulted in optimum conditions for Phomopsis spp. to infect seed. Harvest was not delayed in 2010 , and almost no seed harvested from plots in 2010 were infected with Phomopsis spp. It is reasonable to conclude that all genotypes in this study were susceptible to these Phomopsis spp. because greater than $50 \%$ of harvested seed for the four genotypes were infected with Phomopsis spp. in 2009. The results of this study to determine fungicide treatment effects on percent seed infected by Phomopsis spp. are not conclusive because data were obtained in only 1 year, and only one soybean genotype was treated with fungicide. The results from 2009 indicate that azoxystrobin treatments had no effect on percentage of AG 4403 harvested seed infected by Phomopsis spp. These results agree with a previous report that the percentage of harvested soybean seed infected by Phomopsis spp. was not affected by foliar application of azoxystrobin (24). Foliar application of azoxystrobin did affect percent seed infected by Phomopsis spp. in Louisiana (16). The reason for differences in effects of azoxystrobin on percentage of seed infected by Phomopsis spp. between these two studies is not clear.

This is the first report of resistance to pod and stem blight in PI 567562A. Other PIs in maturity groups 2 to 8 have been reported resistant to pod and stem blight (8) but resistance to pod and stem blight from these PIs has not been reported to be incorporated into commercial cultivars. There are no commercial varieties available that have advertised resistance to pod and stem blight.

\section{Acknowledgments}

These studies were supported, in part, by the University of Missouri Agriculture Experiment Station. We thank the United Soybean Board for the financial support from soybean check-off dollars through funding of the project (USB number 9261) entitled "Screening Germplasm and Breeding for Resistance to Phomopsis Seed Decay in Soybean", J. Elrod for her efforts in this project, and God for guidance.

\section{Literature Cited}

1. Barnett, H. L., and Hunter, B. B. 1998. Illustrated Genera of Imperfect Fungi, 4th ed. American Phytopathological Society, St. Paul, MN.

2. Bowers, G. R., and Russin, J. S., 1999. Soybean disease management Pages 231-271 in: Soybean Production in the Midsouth. L. G. Heatherly and H. F. Hodges, eds. CRC Press, New York.

3. Bradley, K. W., Sweets, L. E., Bailey, W. C., Wrather, J. A., Weirich, J. W., and Tindall, K. V. 2011. Missouri Pest Management Guide: Corn, Cotton, Grain Sorghum, Rice, Soybean, Winter Wheat. Univ. Mo. Ext. Publ. M171, Columbia.

4. Dann, E. K., Diers, B. W., and Hammerschmidt R. 1999. Suppression of Sclerotinia stem rot of soybean by lactofen herbicide treatment. Phytopathology 89:598-602.

5. Fehr, W. R., Caviness, C. E., Burmood, D. T., and Penington, J. S. 1971 Stage of development descriptions for soybeans, Glycine max (L.) Merrill. Crop Sci. 11:929-931.

6. Graham, M. Y., 2005. The diphenylether herbicide lactofen induces cell death and expression of defense-related genes in soybean. Plant Physiol. 139:1784-1794.

7. Haddad, W. J., Badenhop, N. P., Stammen, A. D., Bean, T. G., Graham, T L., Graham, L. Y., and Landini, S., 2001. Diphenyl ether induction of systemic resistance in plants. World Intellect. Prop. Organ. WO/2001/058268. http://www.wipo.int/patentscope/search/en/search.jsf

8. Kulik, M. M., and Sinclair, J. B., 1999. Pod and stem blight. Pages 32-33 in: Compendium of Soybean Diseases, 4th ed. G. L. Hartman, J. B. Sinclair, and J. C. Rupe, eds. American Phytopathological Society, St. Paul, MN

9. Li, S. 2011. Phomopsis seed decay of soybean. Pages 277-292 in: Soybean-Molecular Aspects of Breeding. A. Sudaric, ed. InTech, Rijeka, Croatia.

10. Little, T. M., and Hills, F. J. 1978. Agriculture Experimentation. John Wiley $\&$ Sons, New York.

11. Mengistu, A., Castlebury, L., Smith, R., Ray, J., and Bellaloui, N. 2009 Seasonal progress of Phomopsis longicolla infection on soybean plant parts and its relationship to seed quality. Plant Dis. 93:1009-1018.

12. Mengistu, A., Ray, J. D., Smith, J. R., and Paris, R. L. 2007. Charcoal rot disease assessment of soybean genotypes using a colony-forming unit index. Crop Sci. 47:2453-2461.

13. Mengistu, A., Reddy, K. N., Zablotowicz, R. M., and Wrather, J. A. 2009 Propagule densities of Macrophomina phaseolina in soybean tissue and soil as affected by tillage, cover crop, and herbicide. Plant Health Progress. Online publication. doi:10.1094/PHP-2009-0130-01-RS

14. Mengistu, A., Smith, J. R., Bellaloui, N., Paris, R. L., and Wrather, J. A. 2010. Irrigation and time of harvest effects on evaluation of selected soybean accessions against Phomopsis longicolla. Crop Sci. 50:2055-2064.

15. Nelson, K. A., Renner, K. A., and Hammerschmidt, R., 2002. Effects of protoporphyrinogen oxidase inhibitors on soybean (Glycine max L.) response, Sclerotinia sclerotiorum disease development, and phytoalexin production by soybean. Weed Technol. 16:353-359.

16. Padgett, B., Schneider, R., and Whitam, K. 2003. Foliar-applied fungicides in soybean disease management. La. Agric. 46:7-9.

17. Paris, R. L., Mengistu, A., Tyler, J. M., and Smith, J. R. 2006. Registration of soybean germplasm line DT 97-4290 with moderate resistance to charcoal rot. Crop Sci. 46:2324-2325. 
18. Saxton, A. M. 1998. A macro for converting mean separation output to letter groupings in Proc Mixed. Pages 1243-1246 in: Proc. 23rd SAS Users Group Int. SAS Institute, Cary, NC.

19. Sinclair, J. B., 1982. Introduction. in: Compendium of Soybean Diseases, 2nd ed. J. B. Sinclair, ed. American Phytopathological Society, St. Paul, MN.

20. Sinclair, J. B. 1999. Phomopsis seed decay. Pages 31-32 in: Compendium of Soybean Diseases, 4th ed. G. L. Hartman, J. B. Sinclair, and J. C. Rupe, eds. American Phytopathological Society, St. Paul, MN.

21. Wrather, J. A., and Koenning, S. R. 2009. Effects of diseases on soybean yields in the United States 1996 to 2007. Plant Health Progress. Online publication. doi:10.1094/PHP-2009-0401-01-RS.

22. Wrather, J. A., Shannon, J. G., Carter, T. E., Bond, J. P., Rupe, J. C., and
Almeida, A. M. R. 2008. Reaction of drought-tolerant soybean genotypes to Macrophomina phaseolina. Plant Health Progress. Online publication. doi:10.1094/PHP-2008-0618-01-RS

23. Wrather, J. A., Shannon, J. G., and Mengistu, A. 2007. Impact of soybean planting date on soil population density of Macrophomina phaseolina. Plant Health Progress. Online publication. doi:10.1094/PHP-2007-091703-RS

24. Wrather, J. A., Shannon, J. G., Stevens, W. E., Sleper, D. A., and Arelli, A P. 2004. Soybean cultivar and foliar fungicide effects on Phomopsis sp. seed infection. Plant Dis. 88:721-723.

25. Wrather, J. A., Sleper, D. A., Stevens, W. E., Shannon, J. G., and Wilson, R. F. 2003. Planting date and cultivar effects on soybean yield, seed quality, and Phomopsis sp. seed infection. Plant Dis. 87:529-532. 